\title{
Discrepancy between the effects of morronside on apoptosis in human embryonic lung fibroblast cells and lung cancer A549 cells
}

\author{
JIAN-PING CHEN ${ }^{1}$, DE-GUO XU ${ }^{1}$, XIAO-YI YU ${ }^{2}$, FENG-MING ZHAO ${ }^{1}$, DONG-QING XU ${ }^{1}$, \\ $\mathrm{XU}_{\mathrm{ZHANG}}{ }^{1}$, BAO-CHANG CAI ${ }^{1}$ and MING-YAN WANG ${ }^{1}$ \\ ${ }^{1}$ Jiangsu Key Laboratory of Chinese Medicine Processing, Nanjing University of Chinese Medicine, \\ Nanjing, Jiangsu 210029; ${ }^{2}$ China Pharmaceutical University, Nanjing, Jiangsu 210009, P.R. China
}

Received July 2, 2013; Accepted December 13, 2013

DOI: $10.3892 / \mathrm{ol} .2014 .1850$

\begin{abstract}
Morroniside is a water-soluble compound extracted from the fruit of Cornus officinalis and is used to protect lung activity against aging. In the present study, the manner in which morroniside regulates normal lung and cancer cells was examined. The human embryonic lung fibroblast (HELF) cell line and lung cancer A549 cell line, and their responses to morroniside treatment, were examined. Results showed that morroniside reverses the apoptotic effect of $\mathrm{H}_{2} \mathrm{O}_{2}$ on HELF cell growth, protecting cell proliferation and normal cell morphology and inhibiting apoptosis. However, these effects were not present in A549 cells. Western blotting showed that morroniside also markedly downregulated retinoblastoma protein in HELF cells. These results suggest that morroniside treatment exhibits different effects on apoptosis in HELF and A549 cells, making it a viable compound for decreasing the side effects of anticancer medicines in normal cells.
\end{abstract}

\section{Introduction}

The fruit of Cornus officinalis is effective for treating liver and lung disease in traditional Chinese medicine (1). In recent decades, the pharmacology and phytochemistry of the fruit of Cornus officinalis have been extensively investigated. Clinical studies have demonstrated that this fruit has anticancer and antioxidative roles $(2,3)$. Based on various clinical roles, several effective water-soluble components of the fruit of Cornus officinalis have been identified. For instance, gallic acid has antitumor properties (4) and oleanolic acid has antiulcer properties and markedly reduces blood pressure and blood glucose

\footnotetext{
Correspondence to: Professor Ming-Yan Wang or Professor Bao-Chang Cai, Jiangsu Key Laboratory of Chinese Medicine Processing, University of Chinese Medicine, 183 Xianling Road, Nanjing, Jiangsu 210049, China

E-mail: dmwmy@163.com

E-mail: bccai@126.com
}

Key words: human embryonic lung fibroblasts cells, apoptosis, morroniside, retinoblastoma protein levels (5). Morroniside is used to suppress the generation of superoxide anions in a concentration-dependent manner, and protects nerve cells from $\mathrm{H}_{2} \mathrm{O}_{2}$-induced oxidation injury $(6,7)$. At the molecular level, morroniside can enhance the activity of alkaline phosphatase and decrease caspase-3 mRNA levels (8). The protection of cell growth by morroniside is hypothesized to be involved in regulation of cell proliferation and apoptosis.

The retinoblastoma $(\mathrm{Rb}) /$ pocket protein family is made up of tumor suppressor proteins involved in cell proliferation, apoptosis and cell differentiation $(9,10)$. The $\mathrm{Rb}$ protein is one of the master regulators of the eukaryotic cell cycle, regulating the G1/G0 phase and also the $S$ and $G 2$ phases (11). Rb protein activity is regulated by phosphorylation. In normal cells during the M-to-G1 transition, the Rb protein is progressively dephosphorylated by protein phosphatase 1, enabling it to bind E2F, blocking transcription of multiple genes involved in cell cycle progression and elongating the G1/G0 phases. Following mitogenic stimulation of the cell, the $\mathrm{Rb}$ protein is phosphorylated by cyclin-dependent kinase (CDK) 4/6-cyclin D complexes. Phosphorylation inactivates the $\mathrm{Rb}$ protein, resulting in release of E2F, enabling E2F to transcriptionally activate genes that facilitate the G1/S transition and $\mathrm{S}$ phase. The $\mathrm{Rb}$ protein remains phosphorylated/inactive throughout the $S, G 2$ and $\mathrm{M}$ phases through hyperphosphorylation by cyclin E/CDK2 complexes (12-15).

The present study showed that morroniside decreases cell apoptosis induced by $\mathrm{H}_{2} \mathrm{O}_{2}$ in HELF cells but not in A549 cells. Additionally, the $\mathrm{S}$ phase of the cell cycle was returned to normal function and $\mathrm{Rb}$ protein levels were downregulated by morroniside. These results indicate that the effects of morroniside on HELF and A549 cells may correlate with the regulation of $\mathrm{Rb}$ protein levels and $\mathrm{S}$ phase length.

\section{Materials and methods}

Cells and reagents. HELF and A549 cells were purchased from Shanghai Institute of Biochemistry and Cell Biology (Shanghai, China). Morroniside was provided by Jiangsu ZhongKang New Drug Fingerprint R\&D Co., Ltd (Nanjing, China) at a purity of $>98 \%$; MTT, acridine orange (AO), ethidium bromide (EB), RNase A, propidium iodide (PI) and trypsin were purchased from Sigma (St. Louis, MO, USA). RPMI 1640 medium was obtained from Gibco-BRL (Carlsbad, 
CA, USA) and fetal bovine serum (FBS) was from Sijiqing Biotechnology (Hangzhou, China). Cell culture and drug incorporation. HELF and A549 cells were cultured in RPMI 1640 medium with $10 \%$ (v/v) FBS, $100 \mathrm{U} / \mathrm{ml}$ streptomycin and $100 \mathrm{U} / \mathrm{ml}$ penicillin, at $37^{\circ} \mathrm{C}$ with $5 \% \mathrm{CO}_{2}$. The cells digested with $0.25 \%$ trypsin were cultured in 96 -well plates (for proliferation analysis), 6-well plates (for morphology observation) or flasks (for cell cycle analysis). In all experiments, HELF/A549 cells were cultured without treatment (normal control), with $300 \mu \mathrm{M} \mathrm{H}_{2} \mathrm{O}_{2} / 0.2 \mathrm{nM}$ staurosporine (model) or with combined treatment of $\mathrm{H}_{2} \mathrm{O}_{2}$ /staurosporine and morroniside at various doses $(12.5,25,50,100$ and $200 \mu \mathrm{g} / \mathrm{ml})$.

Cell proliferation analysis. Cell proliferation was determined by MTT assay. HELF cells in exponential growth were seeded at a final concentration of $6 \times 10^{4}$ cells $/ \mathrm{ml}$ in a 96-well plate. At 50\% confluency, the cells were pretreated with morroniside at various concentrations for $2 \mathrm{~h}$, exposed to $\mathrm{H}_{2} \mathrm{O}_{2}$ or staurosporine $(0.2 \mathrm{nM})$ and incubated for $48 \mathrm{~h}$. Next, $50 \mathrm{ml}$ MTT $(1 \mathrm{mg} / \mathrm{ml})$ was added to each well, followed by incubation for $4 \mathrm{~h}$ at $37^{\circ} \mathrm{C}$. The supernatants were discarded and the formazan product was dissolved in $100 \mu \mathrm{l}$ dimethyl sulfoxide. The 96 -well plate was agitated on a micro-vibrator for an additional $10 \mathrm{~min}$. The optical density of each well was measured at $\lambda 490 \mathrm{~nm}$ using an enzyme-immunoassay instrument.

Morphological examination. Cell groups were subjected to various designated treatments, as discussed. The cells were observed under a fluorescence microscope and photographed. Cells were seeded at a concentration of $1 \times 10^{5} /$ well in a 6-well culture plate. A cover slip was placed on the bottom of each well to allow cells to grow on the surface as a monolayer. At $40-60 \%$ confluency, the cells were divided into three groups: Normal control group; $\mathrm{H}_{2} \mathrm{O}_{2}$-treated group, treated with $300 \mu \mathrm{M} \mathrm{H}_{2} \mathrm{O}_{2}$ and incubated for $48 \mathrm{~h}$; morroniside plus $\mathrm{H}_{2} \mathrm{O}_{2}$-treated group, pretreated with $100 \mu \mathrm{g} / \mathrm{ml}$ morroniside for $2 \mathrm{~h}$ and exposed to $300 \mu \mathrm{M} \mathrm{H}_{2} \mathrm{O}_{2}$. After a 48-h incubation period, the cell culture was washed with phosphate-buffered saline (PBS), stained with $10 \mu \mathrm{g} / \mathrm{ml} \mathrm{AO} / \mathrm{EB}$ for 2 min and observed under a fluorescence microscope (Olympus BX60; Olympus, Tokyo, Japan).

Flow cytometry. Cells were treated as discussed. After 24-h culture, cells were washed twice with ice-cold PBS buffer ( $\mathrm{pH}$ 7.4) prior to fixing with $75 \%$ ice-cold ethanol and staining with PI $(1 \mathrm{mg} / \mathrm{ml})$ in the presence of $1 \%$ RNAase A for $30 \mathrm{~min}$. The samples were subsequently analyzed by flow cytometry (BD Biosciences, Franklin Lakes, NJ, USA). The Cell Quest software (BD Biosciences) was applied to analyze apoptosis rates and the cell cycle.

Western blotting. HELF cells were lysed in cold lysis buffer [40 mM HEPES ( $\mathrm{pH} 7.5$ ), $150 \mathrm{mM} \mathrm{NaCl}, 1.5 \mathrm{mM}$ $\mathrm{MgCl}_{2}, 1 \mathrm{mM}$ EDTA, $1 \mathrm{mM}$ dithiothreitol and $1 \mathrm{mM}$ fresh phenylmethylsulfonyl fluoride]. Lysates were centrifuged at $12,000 \mathrm{x}$ g for $15 \mathrm{~min}$. The supernatant was collected and the protein concentration was determined by Lowry protein assay. Next, $20 \mu \mathrm{g}$ protein was loaded in each well, electrophoresed by SDS-PAGE and transferred onto nitrocellulose membranes.
The membranes were blocked with $5 \%$ non-fat dried milk in PBS with $0.5 \mathrm{ml} / 1$ Tween-20 for $2 \mathrm{~h}$ at room temperature, and incubated overnight at $4{ }^{\circ} \mathrm{C}$ with primary antibodies against human P16, P27, P53 or Rb proteins, purchased from Beyotime (Nanjing, China). This was followed by incubation with a horseradish peroxidase-conjugated secondary antibody (Bioworld Technology, St. Louis Park, MN, USA) at room temperature for $1 \mathrm{~h}$. Enhanced chemiluminescence was used to detect the results.

Statistical analysis. The statistical analysis among various groups was performed using one-way analysis of variance with Scheffé's test. All data were processed with SPSS software (SPSS, Inc., Chicago, IL, USA). The results were expressed as the mean $\pm \mathrm{SD}$. $\mathrm{P}<0.05$ and $\mathrm{P}<0.01$ were considered to indicate a statistically significant and highly statistically significant difference, respectively.

\section{Results}

Morroniside reverses inhibition of cell growth in human embryonic lung fibroblasts cells induced by $\mathrm{H}_{2} \mathrm{O}_{2}$. Preliminary data indicated that the crude extract of morroniside protected the lung in aging and immune-defective mice. In order to understand whether morroniside regulates the proliferation of lung cells, the growth of HELF cells treated with morroniside (98\% purity) was examined. MTT was applied to analyze HELF growth under $\mathrm{H}_{2} \mathrm{O}_{2}$ treatment and with the addition of morroniside at various concentrations (Fig. 1A). Results showed that $300 \mu \mathrm{M} \mathrm{H}_{2} \mathrm{O}_{2}$ treatment decreased HELF growth, as expected, while $100 \mu \mathrm{g} / \mathrm{ml}$ morroniside markedly increased HELF cell growth and decreased the negative effect on growth under $\mathrm{H}_{2} \mathrm{O}_{2}$ treatment. This indicates that morroniside protects HELF proliferation against $\mathrm{H}_{2} \mathrm{O}_{2}$ treatment.

Additionally, under a fluorescence microscope, staining with mixed dye (AO/EB) showed that, compared with the normal control group, the amount of cells was lower in the model group but increased with the treatment of $100 \mu \mathrm{g} / \mathrm{ml}$ morroniside. The control group was morphologically normal, with evenly-stained bright green nuclei. Under $\mathrm{H}_{2} \mathrm{O}_{2}$ treatment, however, the cells were wrinkled and chromatin was condensed and orange in color. The addition of morroniside morphologically restored the cells back to the morphological appearance of the control group (Fig. 1B). These results indicate that morroniside blocks the negative effect of $\mathrm{H}_{2} \mathrm{O}_{2}$ treatment on HELF cells.

Morroniside specifically antagonizes $\mathrm{H}_{2} \mathrm{O}_{2}$-induced $\mathrm{HELF}$ apoptosis. $\mathrm{H}_{2} \mathrm{O}_{2}$ treatment can result in various consequences in terms of cell growth, including apoptosis, autophagy and necrosis (16). To understand whether morroniside treatment is involved in the regulation of apoptosis, flow cytometry was used to analyze the cell cycle and rate of apoptosis in HELF cells under various treatments (Fig. 2A). Results demonstrated that $300 \mu \mathrm{M} \mathrm{H}_{2} \mathrm{O}_{2}$ induced a $41 \%$ rate of apoptosis in HELF cells (control group apoptosis rate, $0.48 \%$ ), however, the addition of morroniside $(100 \mu \mathrm{g} / \mathrm{ml}) 2 \mathrm{~h}$ prior to $\mathrm{H}_{2} \mathrm{O}_{2}$ treatment maintained the apoptotic rate at the normal control level, indicating that morroniside protected HELF cells from the $\mathrm{H}_{2} \mathrm{O}_{2}$-induced apoptosis. Furthermore, $\mathrm{H}_{2} \mathrm{O}_{2}$ 
A

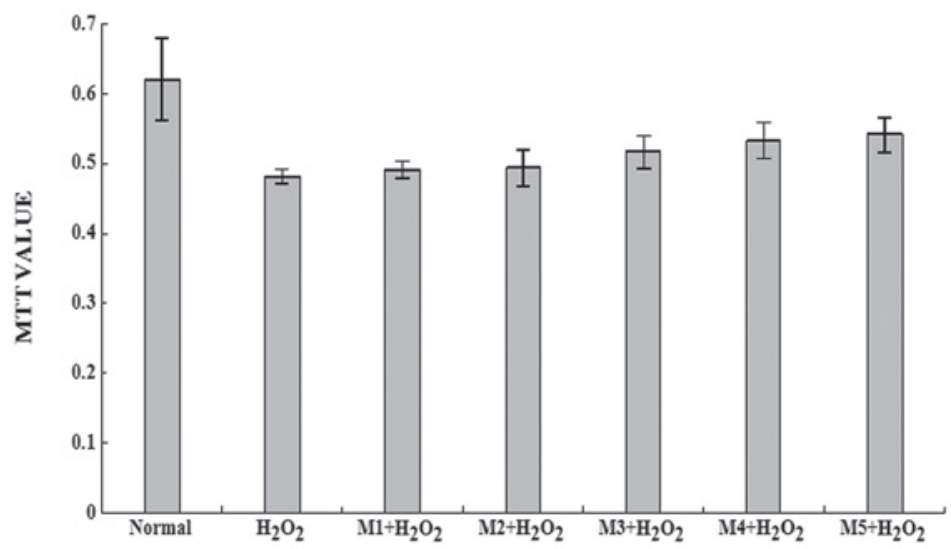

B

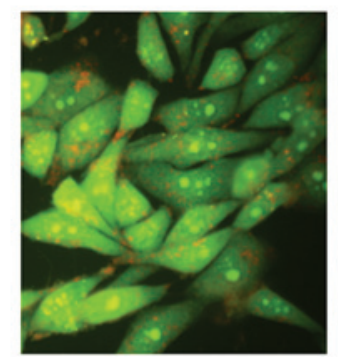

Control

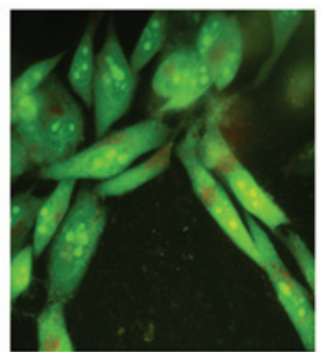

$\mathrm{M}+\mathrm{H}_{2} \mathrm{O}_{2}$

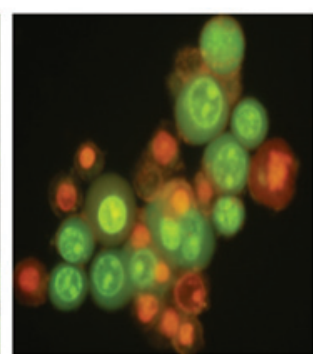

$\mathrm{H}_{2} \mathrm{O}_{2}$

Figure 1. Morroniside reverses $\mathrm{H}_{2} \mathrm{O}_{2}$-induced inhibition of HELF growth and improves cell morphology by preventing cell deformation and maintaining the same appearance as the control group. HELF cells were treated without or with $\mathrm{H}_{2} \mathrm{O}_{2}$ or with a combination of $\mathrm{H}_{2} \mathrm{O}_{2}$ and morroniside at various concentrations. (A) HELF cell growth was measured by MTT. (B) Morphology of HELF cells with acridine orange/ethidium bromide staining. M, morroniside; M1-5, 12.5, 25, 50, 100 and $200 \mu \mathrm{g} / \mathrm{ml}$ morroniside, respectively; HELF, human embryonic lung fibroblast.

A

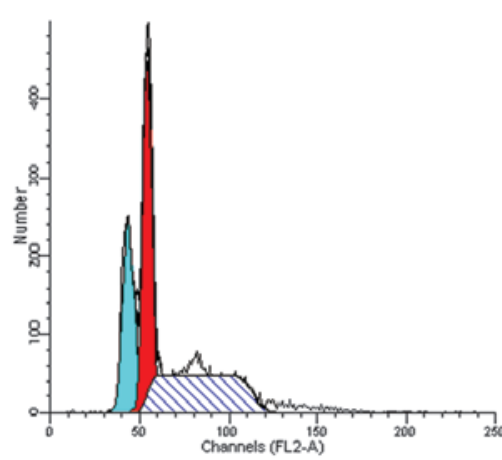

$\mathrm{H}_{2} \mathrm{O}_{2}$

$\mathbf{B}$

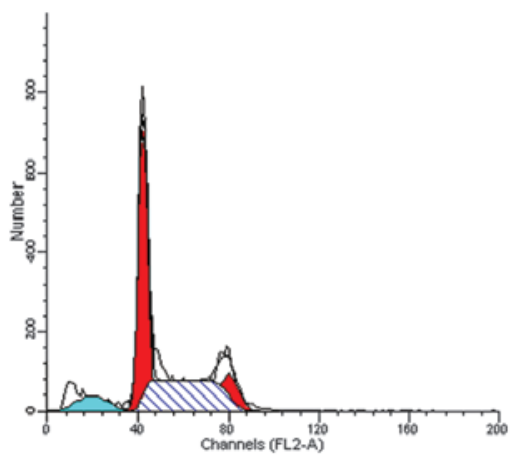

S

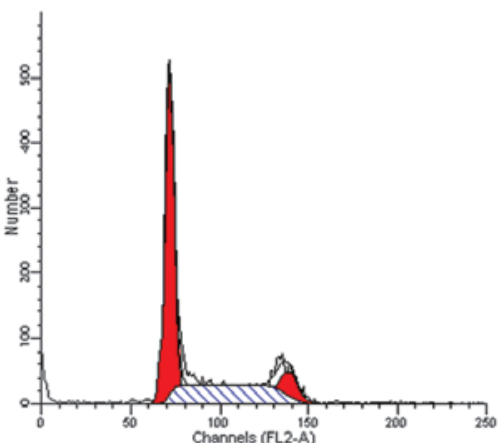

$\mathrm{M}+\mathrm{H}_{2} \mathrm{O}_{2}$

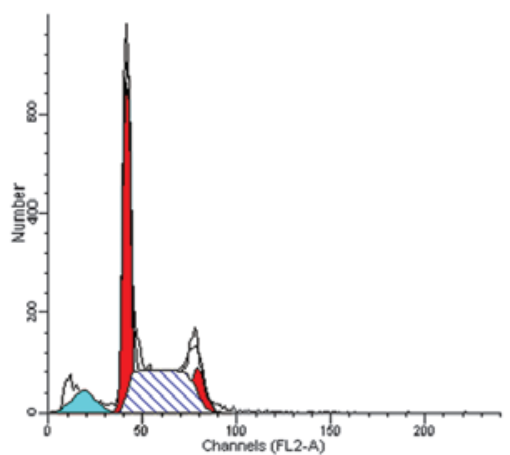

$M+S$

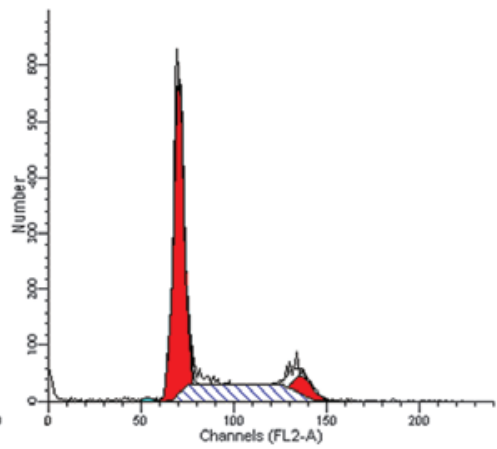

Control

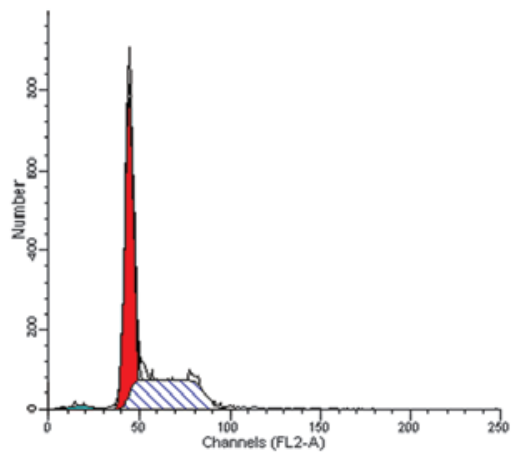

Control

Figure 2. Morroniside antagonizes $\mathrm{H}_{2} \mathrm{O}_{2}$-induced apoptosis in HELF cells but not in A549 cells. (A) Flow cytometry of HELF apoptosis. In $300 \mu \mathrm{M} \mathrm{H}_{2} \mathrm{O}_{2}$-treated HELF cells, the apoptotic rate was $28.3 \%$ following 24-h culture, while the addition of $100 \mu \mathrm{g} / \mathrm{ml}$ morroniside $2 \mathrm{~h}$ prior to $\mathrm{H}_{2} \mathrm{O}_{2}$ treatment inhibited $\mathrm{HELF}$ cell apoptosis. (B) Morroniside did not inhibit the apoptosis of HELF cells induced by staurosporine. Following $0.2 \mathrm{nM}$ staurosporine treatment of HELF cells, the apoptotic rate was $8.1 \%$ after 24 -h treatment. However, the addition of $100 \mu \mathrm{M}$ morroniside $2 \mathrm{~h}$ prior to staurosporine treatment showed a similar apoptotic rate of $8.3 \%$. M, morronside; S, staurosporine; HELF, human embryonic lung fibroblast. Blue, apoptotic cells; red, normal cells. 
A

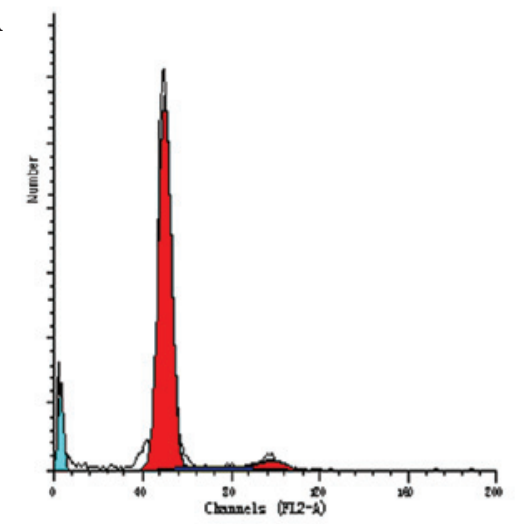

$\mathrm{H}_{2} \mathrm{O}_{2}$

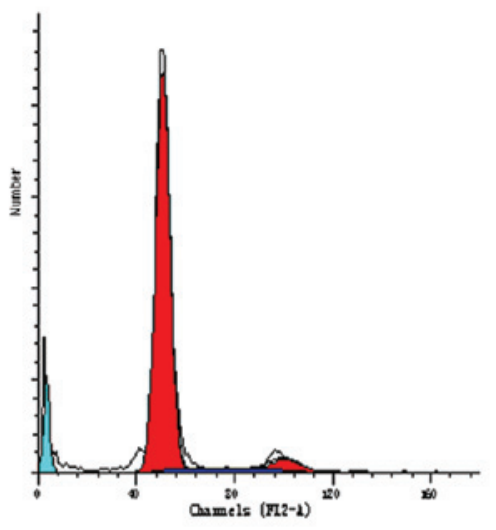

$\mathrm{M}+\mathrm{H}_{2} \mathrm{O}_{2}$

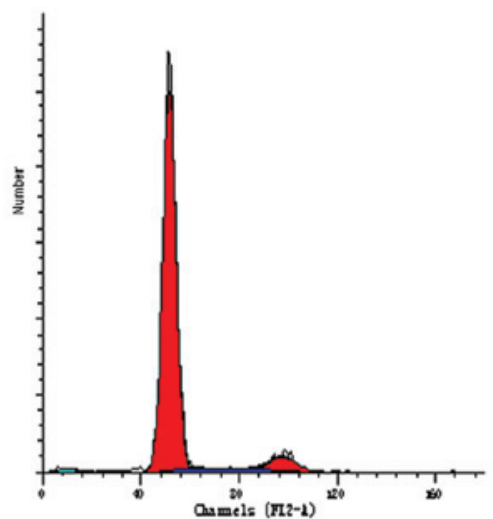

Control

B

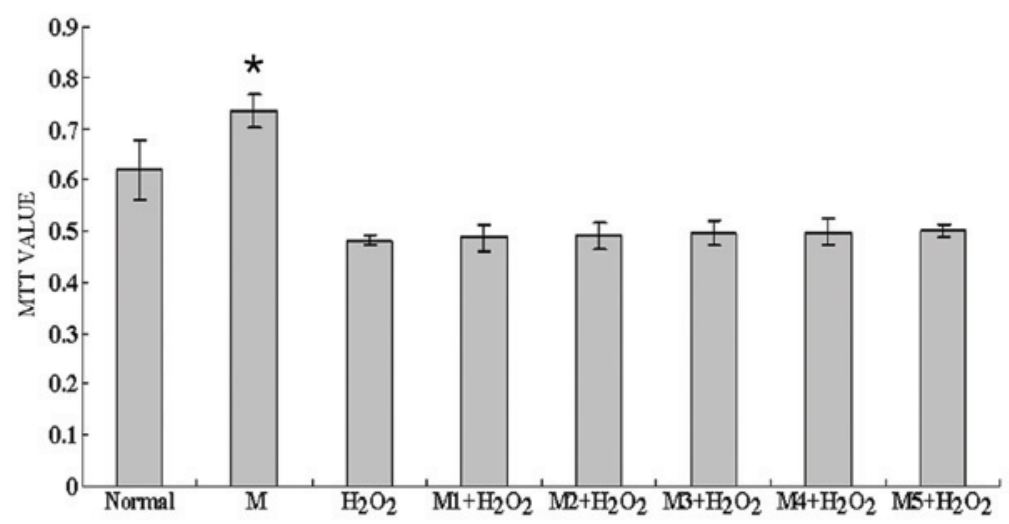

Figure 3. Morroniside does not inhibit the apoptosis of A549 cells induced by $\mathrm{H}_{2} \mathrm{O}_{2}$. (A) A549 apoptosis under various treatments. Treatment with $300 \mu \mathrm{M}$ $\mathrm{H}_{2} \mathrm{O}_{2}$ induced an $8.1 \%$ rate of apoptosis in A549 cells. The addition of $100 \mu \mathrm{g} / \mathrm{ml}$ morroniside 2 h prior to $\mathrm{H}_{2} \mathrm{O}_{2}$ treatment showed a similar apoptotic rate of $7.8 \%$. (B) A549 cell growth was measured by MTT. Compared with the control group, morroniside significantly increased A549 growth, $\mathrm{H}_{2} \mathrm{O}_{2}$ treatment decreased cell growth and combined treatment of morroniside and $\mathrm{H}_{2} \mathrm{O}_{2}$ did not improve cell growth (P<0.01). $\mathrm{M}$, morroniside; $\mathrm{M} 1-5,12.5,25,50,100$ and $200 \mu \mathrm{g} / \mathrm{ml}$ morroniside, respectively. *Compared with the $\mathrm{H}_{2} \mathrm{O}_{2}$ group the addition of morroniside showed no significant difference to cell growth. Blue, apoptotic cells; red, normal cells.

treatment elongated the $\mathrm{S}$ phase of the cell cycle, while morroniside markedly decreased the duration of the $\mathrm{S}$ phase to that of normal cells, suggesting that morroniside repairs the dysfunctional regulation of the $\mathrm{S}$ phase induced by $\mathrm{H}_{2} \mathrm{O}_{2}$. To understand whether morroniside regulates the common signaling pathways of apoptosis, staurosporine was used as an apoptotic model to examine the consequences of morroniside treatment on staurosporine-induced apoptosis (Fig. 2B). Flow cytometry results showed that $0.2 \mathrm{nM}$ staurosporine caused an $8.1 \%$ apoptotic rate in HELF cells and the combination of morroniside and staurosporine resulted in a similar apoptotic rate of $8.3 \%$. This suggests that morroniside may not reverse apoptosis induced by staurosporine. Therefore, morronoside is involved in $\mathrm{H}_{2} \mathrm{O}_{2}$ signaling and likely to regulate the upstream apoptotic signaling pathways.

Morroniside does not reverse apoptosis of lung cancer A549 cells. As morroniside restored HELF apoptosis to normal levels, the apoptotic effects of morroniside were examined in cancer cells. The A549 cell line was used for the same experiments and $100 \mu \mathrm{g} / \mathrm{ml}$ morroniside was applied $2 \mathrm{~h}$ prior to $\mathrm{H}_{2} \mathrm{O}_{2}$ treatment. Flow cytometry showed that $100 \mu \mathrm{M}$ $\mathrm{H}_{2} \mathrm{O}_{2}$ induced HELF apoptosis at rate of $8.1 \%$. Notably, the combination of morroniside and $\mathrm{H}_{2} \mathrm{O}_{2}$ caused a $7.8 \%$ rate of apoptosis (Fig. 3A) and MTT results showed that morroniside markedly increased A549 proliferation but did not reduce the $\mathrm{H}_{2} \mathrm{O}_{2}$-induced inhibition of A549 cell growth. These primary results indicate that morroniside has no apparent effect on A549 growth under $\mathrm{H}_{2} \mathrm{O}_{2}$ treatment (Fig. 3B).

Morroniside regulates the S phase of the cell cycle and negatively regulates $R b$ protein levels. In normal HELF cells, flow cytometry showed that the proportion of the cell cycle in the $\mathrm{S}$ phase was $28.8 \%$ and that $\mathrm{H}_{2} \mathrm{O}_{2}$ increased this to $48.5 \%$. By contrast, morroniside reduced this to $28.3 \%$, indicating that morroniside regulates the cell cycle during the $\mathrm{S}$ phase (Fig. 4A). To elucidate the potential signaling pathways regulated by morroniside, the levels of P16, P27, P53 and Rb proteins, all critical factors in the $\mathrm{S}$ phase and the regulation of cell growth and apoptosis, were examined (17). Western blotting showed that $\mathrm{Rb}$ and P53 proteins were markedly reduced under the combined treatment of morroniside and $\mathrm{H}_{2} \mathrm{O}_{2}$. However, $\mathrm{H}_{2} \mathrm{O}_{2}$ treatment slightly increased P53 protein levels but did not affect $\mathrm{Rb}$ protein levels, suggesting that $\mathrm{Rb}$ protein levels are not regulated by $\mathrm{H}_{2} \mathrm{O}_{2}$ but may mediate $\mathrm{H}_{2} \mathrm{O}_{2}$-induced apoptosis (Fig. 4B). The loss of $\mathrm{Rb}$ protein positively correlated with cell proliferation. These results suggest that the downregulation of $\mathrm{Rb}$ protein expression 
A

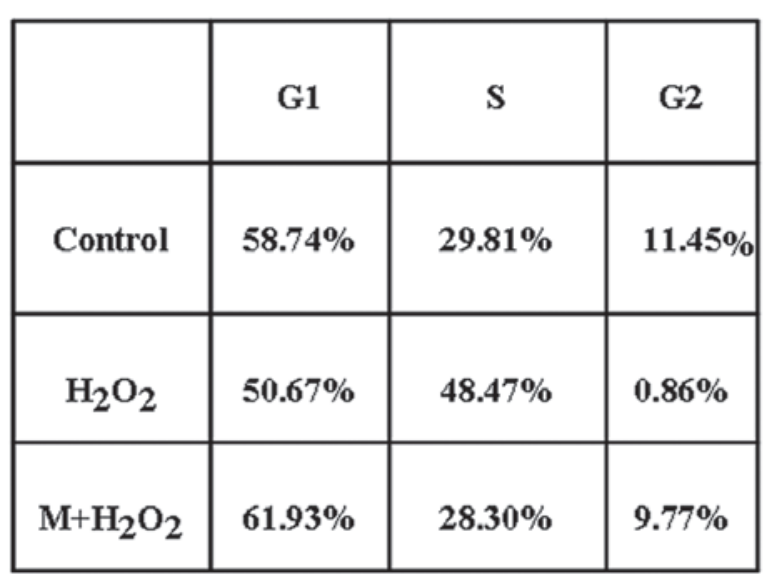

B

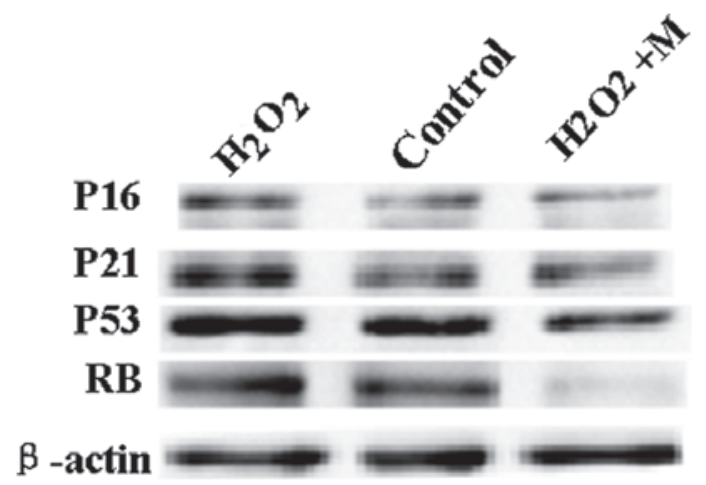

Figure 4. Morroniside mediates $\mathrm{S}$ phase and downregulates Rb protein levels. (A) HELF cell cycle under various treatments. The percentage of cells in $\mathrm{S}$ phase in the control group was $48.47 \%$. However, the addition of morroniside reduced this to normal levels of $28.3 \%$, indicating that morroniside regulates $\mathrm{S}$ phase in HELF cells. (B) Rb protein levels by western blotting. Results showed that $300 \mu \mathrm{M} \mathrm{H}_{2} \mathrm{O}_{2}$ treatment did not change Rb protein levels, while the combined treatment of $100 \mu \mathrm{g} / \mathrm{ml}$ morroniside and $\mathrm{H}_{2} \mathrm{O}_{2}$ markedly downregulated $\mathrm{Rb}$ protein levels. M, morroniside; HELF, human embryonic lung fibroblast; Rb, retinoblastoma.

by morroniside may be relevant to the mediation of $\mathrm{S}$ phase length.

\section{Discussion}

Previous preliminary experiments (data not shown) have shown that morroniside plays a specific role in the protection of lung cell proliferation, suggesting a potential medicinal use of morroniside to protect normal cells from the side effects of anticancer medication. The present study showed that morroniside exhibits differential effects on apoptosis in HELF and A549 cells under $\mathrm{H}_{2} \mathrm{O}_{2}$ treatment. Notably, morroniside significantly reversed the negative effects of $\mathrm{H}_{2} \mathrm{O}_{2}$ on HELF cell growth but not on A549 cells, indicating that morroniside-regulated signaling pathways are relevant for partially differentiating between the signaling pathways in HELF and A549 cells. Furthermore, morroniside protected the $\mathrm{S}$ phase and downregulated $\mathrm{Rb}$ protein, suggesting that the molecular mechanisms of morroniside mediating the cell cycle (S phase) may be relevant to $\mathrm{Rb}$ protein signaling.

Results of the present study suggest that the different signaling pathways of HELF and A549 cell lines interact with $\mathrm{H}_{2} \mathrm{O}_{2}$ signaling and are specific to the regulation of $\mathrm{S}$ phase. $\mathrm{H}_{2} \mathrm{O}_{2}$ treatment was applied to establish a model of hepatocellular oxidative stress, as $\mathrm{H}_{2} \mathrm{O}_{2}$ acts as a harmful factor in these cells, resulting in accumulation of reactive oxygen species (ROS) and an imbalance between the cell oxidation and antioxidant system (18). Results showed that $\mathrm{H}_{2} \mathrm{O}_{2}$ did not increase $\mathrm{Rb}$ protein levels, suggesting that morroniside and $\mathrm{H}_{2} \mathrm{O}_{2}$ signaling may interact downstream of the $\mathrm{Rb}$ protein. The interaction of signaling pathways regulated by ROS and morroniside requires further investigation. Notably, results also showed that morroniside did not reverse staurosporine-induced apoptosis, indicating that morroniside may not directly target the apoptosis signaling pathways, but acts on the upstream molecules beyond the apoptotic signaling pathways. Furthermore, staurosporine, an inhibitor of protein kinase $\mathrm{C}$, was used to establish an apoptosis model through elongation of $\mathrm{G} 2$ phase (19). Morroniside was found to restore the $\mathrm{H}_{2} \mathrm{O}_{2}$-induced imbalance of the $\mathrm{S}$ phase only but not staurosporine-induced G2 phase imbalance, suggesting that morroniside may be an $\mathrm{S}$ phase-specific regulator.

Results of the present study imply that the downregulation of $\mathrm{Rb}$ protein expression may be relevant to $\mathrm{S}$ phase regulation. It is well known that $\mathrm{Rb}$ protein plays roles throughout the cell cycle. The phosphorylation and dephosphorylation of Rb play key roles in the cell cycle (20). Usually, Rb protein levels undergo no significant change through the cell cycle (21). However, results of the present study showed that $\mathrm{Rb}$ protein was markedly downregulated by morroniside. Morronisde also caused the rebalance of the $\mathrm{S}$ phase length in HELF cells, which was previously increased by $\mathrm{H}_{2} \mathrm{O}_{2}$ treatment. It remains unclear how $\mathrm{Rb}$ protein levels are involved in $S$ phase regulation. Identification of the signaling pathways regulated by morroniside and the molecular mechanisms regulating $\mathrm{Rb}$ protein stability require further in vitro and in vivo study.

In conclusion, morroniside was found to inhibit apoptosis in normal HELF cells but not in the A549 cancer cell line. These effects included the protection of cell proliferation and normal cell morphology, and the restoration of the $\mathrm{S}$ phase to normal levels. Furthermore, the interaction between morroniside and $\mathrm{H}_{2} \mathrm{O}_{2}$ signaling was found to be involved in HELF proliferation and apoptosis. Thus, morroniside is a potential compound for clinical amelioration of the side effects of anticancer treatments.

\section{Acknowledgements}

This study was supported by grants from the National Nature Science Foundation of China (no. 30772851), the Priority Academic Program Development of Jiangsu Higher Education Institutions and the National Science and Technology Research Supporting Program in Chinese Medicine in 'The 11th Five-Year Plan' (no. 2006BAI11B08-01). 


\section{References}

1. Liu $\mathrm{H}$ and $\mathrm{Xu} \mathrm{H}$ : Advancement in research of Fructus Corni Officinalis and its main component. Nanjing Zhongyiyao Daxue Xuebao 19: 254-256, 2003 (In Chinese)

2. Zhang L, Yuan Z, Du Y and Wang C: Recent development and prospect of Cornus officinalis. Zhongguo Zhongyao Zazhi 35. 952-956, 2004 (In Chinese).

3. Song Q and Zhou Y: Recent Research on the pharmacological action of Cornus officinalis. Zhongyiyao Xinxi 23: 24-25, 2006 (In Chinese)

4. Li X, Cui L and Zhu D: Research progress on biological effects of gallic acid. Zhongguo Yaoshi 7: 767-769, 2004 (In Chinese).

5. Zhou Z and Yuan D: Pharmacological research progress of oleanolic acid. Zhongguo Yiyuan Yaoxue Zazhi 28: 2031-2033, 2008 (In Chinese).

6. Wei S, Chi H, Kodama H and Chen G: Anti-inflammatory effect of three iridoids in human neutrophils. Nat Prod Res 27: 911-915, 2013.

7. Ai HX, Wang W, Sun FL, Huang WT, An Y and Li L: Morroniside inhibits $\mathrm{H}_{2} \mathrm{O}_{2}$-induced apoptosis in cultured nerve cells Zhongguo Zhong Yao Za Zhi 33: 2109-2112, 2008 (In Chinese).

8. Li M, Wang W, Wang P, Yang K, Sun H and Wang X: The pharmacological effects of morroniside and loganin isolated from Liuweidihuang Wan, on MC3T3-E1 cells. Molecules 15: 7403-7414, 2010

9. Gordon GM and Du W: Conserved RB functions in development and tumor suppression. Protein Cell 2: 864-878, 2011.

10. Poznic M: Retinoblastoma protein: a central processing unit. J Biosci 34: 305-312, 2009.

11. Wikman H and Kettunen E: Regulation of the G1/S phase of the cell cycle and alterations in the RB pathway in human lung cancer. Expert Rev Anticancer Ther 6: 515-530, 2006.
12. Kolupaeva V and Basilico C: Overexpression of cyclin E/CDK2 complexes overcomes FGF-induced cell cycle arrest in the presence of hypophosphorylated Rb proteins. Cell Cycle 11: 2557-2566, 2012.

13. Kolupaeva V and Janssens V: PP1 and PP2A phosphatases - cooperating partners in modulating retinoblastoma protein activation. FEBS J 280: 627-643, 2013.

14. Aksoy O, Chicas A, Zeng T, Zhao Z, McCurrach M, Wang X and Lowe SW: The atypical E2F family member E2F7 couples the p53 and RB pathways during cellular senescence. Genes Dev 26: 1546-1557, 2012.

15. Naqsh e Zahra S, Khattak NA and Mir A: Comparative modeling and docking studies of p16ink4/cyclin D1/Rb pathway genes in lung cancer revealed functionally interactive residue of RB1 and its functional partner E2F1. Theor Biol Med Model 10: 1, 2013.

16. Aiken RJ and Roman SD: Antioxidant systems and oxidative stress in the testes. Oxid Med Cell Longev 1: 15-24, 2008.

17. Ye Y, Wang D, Su C, Rong T and Guo A: Combined detection of $\mathrm{p} 53, \mathrm{p} 16, \mathrm{Rb}$, and EGFR mutations in lung cancer by suspension microarray. Genet Mol Res 8: 1509-1518, 2009.

18. Kohen R and Nyska A: Oxidation of biological systems: oxidative stress phenomena, antioxidants, redox reactions, and methods for their quantification. Toxicol Pathol 30: 620-650, 2002.

19. Antonsson A and Persson JL: Induction of apoptosis by staurosporine involves the inhibition of expression of the major cell cycle proteins at the $\mathrm{G}(2) / \mathrm{m}$ checkpoint accompanied by alterations in Erk and Akt kinase activities. Anticancer Res 29: 2893-2898, 2009.

20. Rubin SM: Deciphering the retinoblastoma protein phosphorylation code. Trends Biochem Sci 38: 12-19, 2013.

21. Burkhart DL, Ngai LK, Roake CM, Viatour P, Thangavel C, Ho VM, Knudsen ES and Sage J: Regulation of RB transcription in vivo by RB family members. Mol Cell Biol 30: 1729-1745, 2010. 